\title{
The effect of melatonin and IAA on the growth of Arabidopsis thaliana cotyledons seedlings in different spectral composition of the light \\ Boyko E.V., Golovatskaya I.F.
}

National Research Tomsk State University, Tomsk, Russia

E-mail: CaterinaSoloveva@gmail.com

Key message. We studied the effect of melatonin and IAA on the growth of Arabidopsis thaliana cotyledons seedlings in red and blue light. The mutual influence of melatonin and IAA on the regulation of cotyledon growth under selective light was shown.

Keywords: Arabidopsis thaliana, auxin, melatonin, selective light, in vitro

Melatonin is a substance of indole nature, is present in almost all prokaryotic and eukaryotic organisms. Like animals, the precursor of melatonin (Mel) in plants is tryptophan, which serves as the precursor of indole-3-acetic acid (IAA). The available data indicate the multiple functions of Mel, which has the signal properties of a regulator of integral physiological processes and is a universal antistressor. Of particular importance in the life of plants is the light factor, characterized by qualitative and quantitative parameters. The regulatory role of light, to a greater extent, is determined by its spectral composition [1]. The functional role of Mel in the regulation of growth under selective light is not clear. In this regard, the aim of this study was to study the effect of Mel and IAA on the growth of A. thaliana cotyledons in red (RL) and blue (BL) light. The object of the study was wild-type A. thaliana Col plants and the axr 1-3 mutant line with impaired transduction of the auxin signal. The plants were grown for 7 days under sterile conditions on a solid nutrient medium Murashige and Skoog, not containing (control) or containing $0.1 \mathrm{pM} \mathrm{Mel,} 1 \mathrm{nM}$ IAA, $0.1 \mathrm{pM} \mathrm{Mel}+1 \mathrm{nM}$ IAA (experiment) on RL and BL (140 \pm 10 $\mu \mathrm{mol} / \mathrm{m} 2 \mathrm{~s})$.

As a result of the study, we found for both lines a greater stimulating effect of BL on the extension of the surface of the cotyledons compared with the action of RL. It was shown that $1 \mathrm{nM}$ IAA had an inhibitory effect on the growth of wild-type cotyledons on BL. In turn, $0.1 \mathrm{pM}$ Mel had a stimulating effect on RL and an inhibitory effect on BL in both lines. Great sensitivity to Mel was manifested in the wild type. With the combined action of factors on RL, IAA removed the stimulating effect of Mel, while on BL IAA reduced the inhibition caused by Mel. Thus, the mutual influence of melatonin and IAA on the regulation of cotyledon growth under selective light was shown.

\section{Влияние мелатонина и ИУК на рост семядолей проростков Arabidopsis thaliana на свету разного спектрального состава}

Бойко Е.В., Головацкая И.Ф.

Федеральное государственное автономное образовательное учреждение высшего образования «Национальный исследовательский Томский государственный университет», Томск, Россия

\begin{abstract}
Аннотация. Исследовали влияние мелатонина и ИУК на рост семядолей проростков Arabidopsis thaliana на красном и синем свету. Было показано взаимное влияние мелатонина и ИУК в регуляции роста семядолей на селективном cвету.
\end{abstract}

Ключевые слова: Arabidopsis thaliana, ауксин, мелатонин, селективный свет, in vitro

Мелатонин - вещество индольной природы, присутствует практически во всех прокариотических и эукариотических организмах. Как и у животных, предшественником мелатонина (Мел) в растениях является триптофан, служащий предшественником индол-3-уксусной кислоты (ИУК). Имеющиеся данные свидетельствуют о множественных функциях Мел, который обладает сигнальными свойствами регулятора интегральных физиологических процессов и является универсальным антистрессором. Особое значение в жизнедеятельности растений играет световой фактор, характеризующийся качественными и количественными параметрами. Регуляторная роль света, в большей степени, определяется его спектральным составом [1]. Функциональная роль Мел в регуляции роста в условиях селективного света не ясна. В связи с этим целью данного исследования было изучение влияния Мел и ИУК на рост семядолей $A$. thaliana на красном (КС) и синем (СС) свету. Объектом исследования были растения A. thaliana дикого типа Соl и мутантной линии axr 1-3 с нарушенной трансдукцией сигнала ауксина. Выращивание растений осуществляли в течение 7 дней в стерильных условиях на твердой питательной среде Мурасиге и Скуга, не содержащей (контроль)

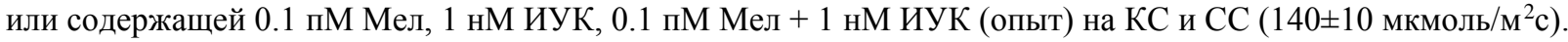

В результате проведенного исследования нами было установлено для обеих линий большее стимулирующее действие СС на растяжение поверхности семядолей по сравнению с действием КС. Показано, что 1 нМ ИУК оказывала ингибирующее действие на рост семядолей дикого типа на СС. В свою очередь 0.1 пМ Мел оказывал стимулирующий эффект на КС и ингибирующий на СС у обеих линий. Большая чувствительность к Мел проявлялась у дикого типа. При совместном действии факторов на КС ИУК снимала стимулирующий эффект Мел, тогда как на СС ИУК снижала вызванное Мел ингибирование. Таким образом показано взаимное влияние Мел и ИУК в регуляции роста семядолей на селективном свету.

1. Golovatskaya I.F., Karnachuk R.A. Role of green light in physiological activity of plants // Russ. J. Plant Physiol. 2015. Vol. 62, № 6. P. 727-740. 